\title{
KOMPLEKSITAS KEHIDUPAN (ANAK) \\ PEREMPUAN PEKERJA SEKS: ANALISIS \\ GEGURITAN ASIH PUNK ROCK KARYA WIJI \\ THUKUL
}

\section{Joko Susilo}

Mahasiswa Magister Kajian Sastra dan Budaya, Universitas Airlangga, Surabaya / Pegiat sastra di Paguyuban Karawitan Sastra Jendra (Pakarsajen)

Surel: aljokosusilo@gmail.com

\begin{abstract}
During new order regime in Indonesia, it was acclaimed that there were only three poets whose poetries raised the issue of regime oppression. One of them was Wiji Thukul who then suddenly disappeared and left no traces but his poetries. Asih Punk Rock is one of his poetries that he wrote in Javanese. It tells a story about life of a female sex worker named Asih. By applying Michael Riffaterre method in analyzing poetry, I discover that Wiji Thukul were trying to raise the issue of sexual violence against women/girls and discrimination against female sex workers, an issue that was considered less important during new order regime and even until today.
\end{abstract}

Keywords: geguritan, violence against women/girls, discrimination against female sexual worker,

\section{Pendahuluan}

Pada masa orde baru, tidak banyak penyair yang karyanya bertemakan perlawanan terhadap penindasan rezim masa itu. Tercatat, hanya ada tiga penyair yang secara terbuka melawan rezim yang kala itu tengah berkuasa, yakni W.S. Rendra, Wiji Thukul dan Sapardi Djoko Damono. Di antara 
ketiganya, hanya Wiji Thukul lah yang berasal dari golongan rakyat jelata (Waluyo [dalam Satoto dan Fananie, 2000: 271-284]). Ia dibesarkan di sebuah kampung yang mata pencaharian sebagian besar penduduknya adalah penarik becak. Terjerat hutang rentenir adalah hal yang menimpa mereka sehari-hari. Wiji Thukul sendiri melakukan pekerjaan yang bermacammacam untuk menafkahi hidupnya. Ia pernah menjadi calo tiket bioskop, tukang plitur mebel, dan lain-lain. Akan tetapi, kecintaannya terhadap kesenian tak pernah sirna oleh sulitnya kehidupannya ((Borch, 2007).

Tampaknya, latar belakang hidupnya itulah yang membuatnya banyak menulis tentang ketidakadilan dan penindasan seperti yang dituangkannya dalam Aku Ingin Jadi Peluru, Para Jendral Marah-Marah, Aku Diburu Pemerintahku Sendiri dan lain-lain. Kekuatan katanya ini rupanya meresahkan penguasa di masa itu, sehingga di kalangan aktivis muncullah dugaan bahwa ia "dihilangkan" seperti yang terjadi pada para aktivis pelawan orde baru lainnya.

Wiji Thukul memang terkenal dengan sikap politiknya yang lugas. Karya-karya Wiji Thukul pun dikenal sebagai karya yang mendasarkan pada fakta, sehingga seluruh permasalahan yang muncul adalah kasus nyata, dan bukaan sebuah fiksi. Ia juga tak segan menunjukkan keberpihakannya dengan jelas pada yang tertindas. Ia pernah mengatakan bahwa sajak harus bertolak pada kenyataan dan harus mempunyai peran bagi masyarakat. Untuk itulah kemudian ia mengenalkan model sastra ngamen. Ia berpendapat bahwa kesenian harus diapresiasi oleh rakyat, dan bukan oleh Dewan Kesenian (Borch, 1990).

Namun, Wiji Thukul sebenarnya tidak hanya menulis karya puisi yang bertemakan perlawanan terhadap rezim orde baru (sebagaimana yang 
diketahui secara umum), tetapi ia juga mengangkat isyu tentang perempuan - sesuatu yang tidak banyak diapresiasi dari karya-karyanya. Selain itu, ia tidak saja menulis dalam bahasa Indonesia, tetapi juga menulis puisi dalam bahasa Jawa yang dikenal sebagai geguritan (Tempo, 2013). Asih Punk Rock adalah salah satu geguritan yang mengusung isyu tentang perempuan. Geguritan ini merupakan salah satu geguritan yang terdapat dalam Antologi Puisi Jawa: Geguritan Iki Mung Pengin Kandha, antologi puisi bersama Keliek Eswe dan Sugiarto B. Darmawan yang diterbitkan pada tahun 1987 oleh Taman Budaya Jawa Tengah di Surakarta (ibid.). Fakta bahwa tidak banyak yang mengapresiasi geguritan inilah yang membuat saya tertarik untuk menelaah geguritan Asih Punk Rock.

\section{Metode Analisis}

Salah satu tokoh dalam dunia sastra yang mengenalkan cara menganalisis puisi adalah Michael Riffaterre. Ia mengemukakan ada empat langkah yang harus diperhatikan dalam menganalisis sebuah puisi (Salam, 2009; Pradopo, 1995; Faruk, 2012).

Pertama, memerhatikan ekspresi tidak langsung. Ekspresi tidak langsung dapat ditemui dalam bahasa kiasan; perusakan makna (distortion) yaitu adanya ambiguitas, kontradiksi dan penggunaan kata yang artinya tidak sesuai dengan kamus; serta penciptaan makna (creating) yang .terjadi karena adanya pengorganisasian ruang ruang teks seperti enjabemen (peloncatan baris dalam sajak), tipografi (tata huruf), homolog (persejajaran bentuk atau baris).

Kedua, membaca secara heuristik dan hermeneutik. Pembacaan heuristik adalah pembacaan sesuai dengan tata bahasa normatif atau dapat 
dikatakan sebagai sistem semiotik tingkat pertama, sedangkan pembacaan hermeneutik adalah proses intepretasi untuk menemukan arti (significance) atau dapat dikatakan sebagai sistem semiotik tingkat kedua.

Ketiga, mengindentifikasi matriks, model, dan varian. Untuk mendapatkan makna puisi secara mendalam, maka kita perlu mengetahui temanya terlebih dahulu. Caranya adalah mencari matriks, model, dan varian. Matriks merupakan abstrak dari suatu puisi. Matriks ditransformasikan dalam model yang dapat ditemukan berupa kiasan-kiasan. Model sendiri ditransformasikan melalui varian-varian yang dapat berupa baris atau bait-bait. Setelah itu, kita baru bisa menentukan temanya.

Keempat, menelusuri hipogram, yaitu teks yang melatari terciptanya karya tersebut. Teks dalam hal ini bisa berarti suatu situasi dalam masyarakat.

\section{Pembahasan}

Berikut adalah teks geguritan Asih Punk Rock yang ditulis Wiji Thukul pada tahun 1987. Saya sengaja mencetak miring bait-bait dalam geguritan untuk membedakannya dengan terjemahan yang saya buat dalam bahasa Indonesia. Sedangkan untuk penggunaan tanda baca dan persejajaran bentuk/baris, saya tulis sebagaimana yang ditulis oleh Wiji Thukul.

“Aja takon ngendi omahku mas!”

Bapakku pegatan kawin maneh karo

prawan

Adhiku papat sekolahe berantakan

saben ndina usrek aku ora kerasan 
“Aja takon piro umurku mas!”

Telung taon kepungkur aku kelas

loro smp

Prawanku ilang dimaling lanangan

"Aja takon iki jam pira mas!"

Wengi iki aku kelonana

Ora bakal ana wong nggoleki

(Asu! ning apa kowe ora kandha

yen lagi bulanan Asih?)

Solo, 24.7.87

"Jangan bertanya di mana rumahku mas!"

Bapakku cerai [dengan ibuku] kawin lagi dengan

perawan

Adikku empat sekolahnya berantakan

tiap hari gelisah aku jadi tidak kerasan

"Jangan bertanya berapa umurku mas!

Tiga tahun yang lalu aku kelas

dua smp

Keperawananku hilang dicuri laki-laki

"Jangan bertanya ini jam berapa mas!"

Malam ini temani aku tidur

Tidak akan ada orang yang mencari

(Anjing! Tetapi apa kamu tidak bilang sedang datang bulan Asih?)

Solo 24.7.87

\section{Ekspresi Tidak Langsung: Bahasa Kiasan}

Meskipun Wiji Thukul dikenal sebagai penyair yang lugas, tetapi ekpresi tidak langsung masih dapat ditemui dalam karya Asih Punk Rock 
melalui kata dimaling (dicuri) dan kelonana (menemani tidur) yang merupakan bahasa kiasan.

Prawanku ilang dimaling lanangan adalah kiasan untuk tindakan perkosaan. Dicuri berasal dari kata kata dasar curi, yaitu [tindakan] mengambil barang seseorang [tanpa izin pemiliknya] (Darmansyah, 2008). Hal ini sama dengan tindakan perkosaan, karena dalam perkosaan, hubungan seks dilakukan tanpa konsensus dari masing-masing orang yang berhubungan seks, atau dengan kata lain dilakukan tanpa izin. Sedangkan, kata kelonana (menemani tidur) adalah kiasan untuk berhubungan seks (bersetubuh). Hal ini dapat dilihat pada bait terakhir saat si tokoh laki-laki mengumpat pada Asih kenapa ia tidak memberitahukan bahwa ia sedang menstruasi.

\section{Pembacaan Heuristik dan Hermeneutik}

Secara heuristik, Asih Punk Rock dapat dibaca sebagai berikut: Asih, seorang anak perempuan berusia 17 (mengacu pada baris telung taon kepungkur aku kelas loro smp), menceritakan kisah hidupnya pada seorang laki-laki yang ia panggil Mas. Ia melarikan diri dari rumah-mengacu pada baris "Aja takon ngendi omahku mas!”. Ayahnya bercerai dengan ibunya, lalu menikah lagi dengan seorang gadis (mengacu pada bapakku pegatan kawin maneh karo prawan). Ia memiliki empat orang adik yang sekolahnya berantakan. Tiap hari, adik-adiknya itu selalu merasa gelisah, sehingga ia menjadi tidak betah.

Selanjutnya, Asih mengatakan pada si Mas untuk tidak menanyakan usianya. Namun, ia mengungkapkan bahwa tiga tahun yang lalu ia duduk di 
kelas dua SMP. Saat itulah, ia kehilangan keperawanan karena diperkosa seorang laki-laki.

Pada akhirnya, Asih ingin si Mas menghabiskan malam bersamanya. Ia ingin mereka berhubungan seks, karena tidak akan ada orang yang mencarinya. Akan tetapi, si Mas kemudian terperanjat kaget saat mengetahui Asih tengah menstruasi.

Sedangkan secara hermeneutik, pembacaan terhadap Asih Punk Rock dapat dilakukan sebagai berikut: Asih adalah anak perempuan usia 17 tahun yang hidup bersama seorang ayah dan ibu (tiri) yang tidak memedulikan anak-anaknya. Akibatnya, kehidupan Asih dan adik-adiknya pun berantakan. Tidak ada dari mereka yang menamatkan pendidikan formal. Kehidupan keluarga yang seperti itu, terutama karena adik-adiknya selalu gelisah, membuat Asih tidak betah. Ia akhirnya memilih melarikan diri dari rumah.

Kapan Asih melarikan diri dari rumah tidak dapat ditemui dalam geguritan. Wiji Thukul hanya memberikan tekanan pada sulitnya kehidupan yang harus dijalani Asih sebagai anak perempuan. Penekanan ini dapat ditemui pada bait 4 saat Asih menceritakan tentang perkosaan yang menimpa dirinya di usia yang sangat muda, 14 tahun (saat ia duduk di kelas dua SMP). Peristiwa itu membuatnya merasa menjadi perempuan nista, sehingga ia pun memilih sekalian untuk menerjuni dunia yang dianggap oleh kebanyakan masyarakat sebagai dunia nista, yaitu dunia pekerja seks.

Akan tetapi, di dunia pekerja seks, Asih justru merasa bisa merdeka. Ia menguasai tubuhnya dan mampu menentukan keinginan birahinyanya. Ia mampu memermainkan seorang laki-laki yang ia suruh menyetubuhinya ketika ia sedang menstruasi. Ini merupakan pemberontakan Asih. 
Kisah Asih adalah kisah ironi yang terjadi pada seorang anak perempuan. Ironi dapat ditemui pada pemilihan usia Asih, yaitu 17 tahun yang merupakan usia istimewa bagi remaja Indonesia, Untuk itulah, di Indonesia muncul istilah sweet seventeen atau dapat diterjemahkan sebagai masa remaja yang manis. Namun, Asih tidak mengalami suka cita masa remaja, sebagaimana remaja (putri) lainnya.

Dalam geguritan Asih Punk Rock, Wiji Thukul hendak mengangkat isyu tentang kehidupan remaja yang menjadi marjinal karena status klas dan status seksualnya (yaitu tidak perawan). Ia ingin menyampaikan bahwa ada anak-anak/remaja-remaja perempuan yang hidup dalam ketidakadilan. Selain itu, ia juga ingin menyampaikan betapa rentannya anak-anak/remaja-remaja perempuan terhadap kekerasan seksual tetapi tak ada yang berbuat apa-apa tentang hal itu, sehingga mereka pada akhirnya harus berjuang sendirian, seperti si tokoh bernama Asih ini.

\section{Matriks, Model, Varian}

Matriks dalam geguritan Asih Punk Rock adalah pemberontakan anak perempuan terhadap ketidakadilan yang menimpanya. Hal ini terutama dapat ditemui pada penggunaan istilah Punk Rock bagi judul geguritan.

Punk Rock adalah genre musik yang muncul di tahun 1976. Kemunculannya dilatari oleh semangat perlawanan terhadap industri musik yang dikuasai oleh konglomerasi multinasional seperti EMI dan CBS (Laing, 1978: 123). Perlawanan itu sendiri tidak terlepas dari ideologi punk sebagai pembangkang. Barker (2011: 347) menyebutkan bahwa punk adalah 'gaya memberontak' yang menciptakan perpaduan pembangkangan dengan karakter abnormal. 
Selanjutnya, model dan variannya dapat ditemui dari bagaimana si tokoh bernama Asih menceritakan tentang dirinya pada si Mas. "Aja takon ngendi omahku mas!" dan "Aja takon piro umurku mas!” adalah ekspresi rasa frustrasi Asih terhadap kehidupannya dan sekaligus ekspresi pemberontakannya.

“Aja takon ngendi omahku mas!” menandakan ketidakpeduliannya terhadap orang tuanya, terutama ayahnya karena ia dan adik-adiknya ditelantarkan (mengacu pada bait 2). "Aja takon piro umurku mas!" menandakan kemarahannya terhadap ketidakadilan yang menimpanya. Ungkapan ini merupakan campuran ekspresi rasa marah, malu dan bersalah atas perkosaan yang menimpa dirinya. Ia marah karena hal itu terjadi di kala usianya masih sangat muda (mengacu pada bait 4), yang dalam hal ini penekanannya adalah pada kalimat aku kelas loro smp. Ia malu dan bersalah karena tak berhasil menjaga keperawanannya yang dianggap merupakan simbol kesucian perempuan.

Lalu, bait terakhir mengisahkan tentang keisengan Asih yang merupakan pemberontakan terhadap ketidakadilan yang menimpanya. Asih dengan sengaja mengajak seorang laki-laki yang ia panggil Mas untuk berhubungan seks di kala ia sedang menstruasi. Melalui bait terakhir inilah, Wiji Thukul mengungkapkan kesendirian yang dihadapi oleh seorang anak/remaja perempuan untuk berjuang melawan ketidakadilan yang menimpanya.

Dari penelusuran varian, model, dan matriks, dapat diketahui bahwa tema geguritan Asih Punk Rock adalah permasalahan tentang ketidakadilan terhadap anak perempuan. Ketidakadilan inilah yang ingin disuarakan Wiji Thukul melalui tokoh bernama Asih. Ia sekaligus mengajak perempuan/anak 
perempuan untuk menyuarakan ketidakadilan ini sebagaimana Asih menyuarakan melalui ceritanya pada si Mas.

\section{Hipogram}

Geguritan Asih Punk Rock ini ditulis Wiji Thukul pada tahun 1987 saat pemerintah orde baru sedang berkuasa. Pada masa itu, pemerintah telah meratifikasi Konvensi Penghapusan Segala Bentuk Diskriminasi Terhadap Perempuan (atau yang diikenal CEDAW) melalui UU No. 7 Tahun 1984 tentang Penghapusan Bentuk Diskriminasi Terhadap Perempuan, tetapi tidak memiliki perangkat-perangkat yang mendukung undang-undang tersebut. Ini menunjukkan lemahnya kehendak dan komitmen pemerintah terhadap isyu kekerasan terhadap perempuan/anak perempuan.

Komisi Nasional Anti Kekerasan Terhadap Perempuan (Komnas Perempuan) baru terbentuk tahun 1998 melalui Keputusan Presiden No. 181 Tahun 1998. Ruang khusus di kepolisian yang diperuntukksn bagi perempuan dan anak korban kekerasan (dikenal sebagai Unit Pelayanan Perempuan dan Anak atau UPPA) baru dibentuk tahun 2007 melalui Peraturan KAPOLRI No. 7 Tahun 2007. Tata cara pemeriksaan saksi dan/atau [perempuan/anak] korban tindak pidana baru disahkan tahun 2008 melalui Peraturan KAPOLRI No. 3 Tahun 2008 (FH Undip, 2013). Pembentukan perangkat-perangkat ini dilatari oleh situasi yang melemahkan perempuan/anak perempuan korban kekerasan, terutama untuk kasus kekerasan seksual.

Dalam kasus kekerasan seksual seperti tindak perkosaan, apa yang menimpa pada perempuan/anak perempuan masih dianggap sebagai aib bagi keluarga dan komunitasnya. Selain itu, tindak kekerasan seksual pun masih 
dikaitkan dengan persoalan moralitas. Dalam hal ini, perempuan/anak perempuan seringkali dituduh sebagai penyebab atau pemberi peluang terjadinya tindak kekerasan seksual karena cara berpakaiannya, cara ia berrelasi sosial, status perkawinannya, pekerjaannya [biasanya terjadi pada perempuan pekerja seks, perempuan yang bekerja hingga larut malam, perempuan yang bekerja di tempat-tempat yang dianggap maksiat seperti bar, karaoke, dan lain-lain], atau keberadaannya pada suatu waktu atau lokasi tertentu. Perempuan juga sering dituduh membiarkan peristiwa kekerasan itu terjadi karena tidak berusaha melawan, mudah tergiur imingiming, atau mudah ditipu (Komnas Perempuan, 2013: 4). Situasi inilah yang menyebabkan korban tidak mudah melaporkan kasus kekerasan seksual yang menimpanya.

"Saya takut hamil dan takut dianggap perempuan bukan baik-baik, tidak bisa menjaga kehormatan diri. Apalagi setelah peristiwa perkosaan itu, pelaku mengancam akan menyebarluaskan kepada teman-teman sekolah kalau saya sudah tidak perawan jika tidak mau mengikuti semua keinginannya..."

(Korban Perkosaan, 14 tahun [dalam Komnas Perempuan, 2013])

Anak perempuan korban perkosaan selanjutnya cenderung menjadi pekerja seks, terutama bagi mereka yang lari dari rumah. Status tidak perawan merupakan salah satu faktor pendorong atau penarik seorang anak perempuan terlibat dalam dunia kerja seks (Shalahudin, 1999).

"Saya sudah tidak perawan dan sudah pergi dari rumah, saya terpaksa melakukannya untuk mendapatkan uang."

(Pe \& Sm 16 tahun; dan Sv, 14 tahun [dalam Shalahudin, 1999])

Inilah ketidakadilan yang dihadapi oleh perempuan/anak perempuan korban perkosaan. Mereka dipersalahkan ketika mengalami kekerasan seksual, dan mereka pun dihakimi ketika menjadi seorang pekerja seks. Pekerjaan seks sendiri adalah pekerjaan yang rentan diskriminasi karena 
masyarakat Indonesia masih memberi label buruk pada pekerja seks (Hartoyo, 2013). Hal ini pun semakin diperburuk oleh kenyataan bahwa pekerjaan seks adalah pekerjaan yang tidak diakui undang-undang, sehingga tidak ada dasar perlindungan hukum bagi pekerja seks (Bawole, 2013: 13). Jadi, sulit bagi pekerja seks untuk melaporkan tindak kekerasan atau kejadian tidak menyenangkan yang menimpa dirinya pada aparat penegak hukum.

“...saat wanita tersebut melapor pada polisi atas kejadian tidak menyenangkan [yang] terjadi pada dirinya ke polisi. Justru ia didiskrminasikan saat polisi tahu pekerjaannya, sang pelaku justru tidak ditindak. Atau saat tertangkap razia, maka seorang pekerja seks akan sulit sekali mendapatkan pembelaan hukum.”

(ibid.: 16)

Itulah dunia pekerja seks yang tak banyak diketahui orang, dan Wiji Thukul ingin memberitakan hal tersebut pada khalayak luas melalui syairsyairnya. Ia ingin masyarakat memahami kompleksitas yang melingkupi kehidupan pekerja seks.

\section{Simpulan}

Telaah puisi dengan menggunakan metode yang dikembangkan oleh Riffaterre memampukan kita untuk memahami puisi dengan lebih mendalam. Langkah-langkah yang ia berikan dapat membuka lapis demi lapis apa yang hendak disampaikan oleh penyair.

Dari telaah terhadap geguritan Asih Punk Rock, dapat diketahui bahwa isyu kekerasan seksual pada perempuan/anak perempuan adalah salah satu isyu yang menjadi perhatian Wiji Thukul. Ia pun menunjukkan keberpihakannya dengan lugas pada perempuan/anak perempuan korban perkosaan dan pekerja seks. Ia tak segan menyuarakan ketidakadilan dan 
penindasan yang terjadi pada mereka saat kebanyakan orang menghakimi dan memberi label buruk pada mereka.

\section{Pustaka Acuan}

Tempo Edisi Khusus Mei 2013.

2013. Konfrontasi Puisi Wiji Thukul. Jakarta: Tempo.

., 2013. Modul Perempuan dan Anak. Laporan Magang Mahasiswa. Semarang: Fakultas Hukum Universitas Diponegoro Fakultas Hukum Universitas Diponegoro.

Barker, C., 2011. Cultural Studies. Bantul: Kreasi Wacana.

Bawole, M.T., 2013. Kajian Hak Azasi Manusia Terhadap Perlakuan Diskriminasi Kepada Pekerja Seks. E-Journal Unsrat, pp.12-23.

Borch, R.v.d., 2007. Sastra Pembebasan: Puisi Wiji Thukul Wijaya (Tanah Air , No 5, edisi Desember 1990). [Daring] Dapat diakses di: http://sastrapembebasan.10929.n7.nabble.com/ sastra-pembebasan-Puisi-Wiji-ThukulWijaya-Oleh-R-von-der-Borch-td14039.html [Diakses 10 Oktober 2013].

Darmansyah, 2008. Kamus Bahasa Indonesia. Batavia Press.

Faruk, 2012. Metode Penelitian Sastra: Sebuah Penjelajahan Awal. Cetakan 1. Yogyakarta: Pustaka Pelajar.

Hartoyo, 2013. Organisasi Pekerja Sex Terlibat HLP Meeting di Bali. [Daring] Dapat diakses di: http://www.ourvoice.or.id/2013/03/pekerja-sexikut-hlp-meeting-di-bali/_[Diakses 2 April 2013].

Komnas Perempuan, 2013. Komnas Perempuan: Kajian Kekerasa Seksual Kenali dan Tangani. [Daring] Dapat diakses di http://www.komnasperempuan.or.id/wpcontent/uploads/2013/12/Kekerasan-Seksual-Kenali-dan-Tangani.pdf [Diakses 26 Desember 2013].

Laing, D., 1978. Intepreting Punk Rock. Marxism Today, pp.123-28.

Pradopo, R.D., 2007. Pengkajian Puisi. Yogyakarta: Gadjah Mada University Press. 
Salam, 2009. Pembelajaran Menulis Puisi Dengan Metode Michael Riffaterre.

Satoto, S. \& Fananie, Z., 2000. Sastra: Ideologi, Politik, dan Kekuasaan. Surakarta: Muhammadiyah University Press.

Shalahuddin, O., 1999. Anak Jalanan Perempuan Semarang. [Daring] Dapat diakses di: http://yayasansetara.org/anak-jalanan-perempuan-semarang/ [Diakses 26 Desember 2013]. 